\title{
Effect of disaster preparedness training towards knowledge of COVID-19 among rural society in Banjararum Village, Kulon Progo Regency, Yogyakarta
}

\author{
Sutono, Bayu Fandhi Achmad* \\ Department of Basic and Emergency Nursing, Faculty of Medicine, Public health, and Nursing, Universitas Gadjah Mada, \\ Yogyakarta, Indonesia
}

\author{
SUBMITTED: 23 January 2021 REVISED: 5 October 2021 ACCEPTED: 11 October 2021
}

KEYWORDS

COVID-19 training

Disaster

preparedness

Rural society
ABSTRACT The number of COVID-19 daily cases in Indonesia reached a record high in 2021, and the prevalence of active cases increased beyond hospital capacity. Disaster preparedness training involving the key role of society is substantial to stop the spread of COVID-19. This study aimed to determine the effect of disaster preparedness training towards the knowledge of COVID-19 pandemic among rural society. The intervention involved 29 participants, who were located in a rural area of the Special Region of Yogyakarta Province. Participants were required to complete the pre-test and post-test to determine the effect of disaster preparedness training on participant knowledge. There was a significant effect of disaster preparedness training on public knowledge about COVID-19 $(P<0.005)$. There was an increase in the mean score between pre-test (9.93) and post-test (11.68). By increasing society's knowledge, the society can play a maximum role in COVID-19 prevention and control measures.

(c) The Journal 2021. This article is distributed under a Creative Commons Attribution-ShareAlike 4.0 International license.

\section{Introduction}

A new strain of coronavirus was found in Wuhan, China named Severe Acute Respiratory Syndrome Coronavirus 2 (SARS-Cov-2) on December $31^{\text {st }}$ 2019. This virus causes the Coronavirus Disease-19 (COVID-19) which infects the human respiratory system and spreads mainly through droplets from nose or mouth when an infected person coughs or sneezes. ${ }^{1}$ By the early 2020, the outbreak started to spread outside China and then spread rapidly throughout the world. On March 11 ${ }^{\text {th }}, 2020$, the World Health Organization (WHO) declared the COVID-19 outbreak as a pandemic. ${ }^{2}$ A month later, the Indonesian President announced COVID-19 as a non-natural national disaster on April $13^{\text {th }}, 2020$. Effective prevention and control measures are still urgently needed to control the number of cases. These measures depend heavily on the community, where the role of the society is increasingly important

\footnotetext{
*Correspondence: bayu.fandhi.a@ugm.ac.id Department of Basic and Emergency Nursing, Faculty of Medicine, Public Health and Nursing, Universitas Gadjah Mada, Yogyakarta, Indonesia.
}

in suppressing the spread of disease as efforts to advance effective drug and vaccine developments and implement global vaccination programs continue. ${ }^{3}$

According to the Sendai Framework Priority 1 "Understanding the Risk", various actions that can be taken for disaster risk reduction consist of developing, promoting, enhancing knowledge and information. ${ }^{4}$ Knowledge is one of the capacity domains as described by UNISDR: "Capacity is the combination of all the strengths, attributes, and resources available within a community, society or organization that can be used to achieve agreed goals". ${ }^{5}$ The exchange of information is one way to strengthen the capacity of communities and individuals to recognize and reduce risks in their surroundings, so they can manage the risks themselves which is part of capacity development. ${ }^{6}$ Knowledge is needed to be able to make the right decisions and take coordinated action. ${ }^{7}$

The occurrence of a pandemic makes knowledge about COVID-19 essentially important for the community. The knowledge that people have about COVID-19 affects their attitudes and practices in 
preventing COVID-19. Studies conducted in South Korea and Indonesia revealed respondents with good knowledge showed good attitudes and behavior towards COVID-19 prevention behavior such as hand hygiene practice, wearing masks, avoiding crowds, and social distancing. ${ }^{8,9}$ Developing the capacity of the community in fighting COVID-19 is expected to reduce the risks posed by the COVID-19 pandemic through preventive and control measures. One of the ways to develop community capacity against disasters is through training. This study aimed to determine the effect of disaster preparedness training toward knowledge of COVID-19 pandemic among the residents in rural society.

\section{Method}

This study was a quasi-experimental study with prepost test design conducted in September 2020 in Banjararum Village, Kulon Progo Regency, Yogyakarta Special Region Province. Using an unpaired categorical formula ${ }^{10}$, there were 29 general public respondents included in this study:

$$
\begin{aligned}
\underline{N_{2}}=\underline{N_{2}} & =\mid\left(\frac{\left(z_{\alpha}+Z_{\beta}\right) S}{X_{1}-X_{2}}\right)^{2} \\
& =\sqrt{\left(\frac{(1.96+1.64) 7.48}{5}\right)^{2}} \\
& =\sqrt{\left(\frac{(3.6) 7.48}{5}\right)^{2}} \\
& =\mid(5.38)^{2} \\
& =\mid(5.38)^{2} \\
& =28.94=29 \text { people }
\end{aligned}
$$

The researchers chose the target population because it is located in a rural area. Based on previous study conducted in China, rural residents are less likely to engage in preventive behavior and tend to have a lower level of information appraisal skills than urban residents. ${ }^{10}$ The researchers conducted face-to-face training in compliance with health protocols with a limited number of participants to avoid crowds and to be able to apply social distancing. The inclusion criteria were people aged $>17$ years old; who are a member of either Disaster Risk Reduction Forum (DRRF), disaster volunteer, or health volunteer (cadres); and have never attended any previous similar training. The exclusion criteria were having physical limitations to participate in disaster preparedness training.

We held a disaster preparedness training in Banjararum village to determine the effect on respondents' knowledge. ${ }^{12,13}$ During the training, respondents received information about COVID-19, Introduction and Prevention; Hand Washing; Use of Masks; and Body Temperature Measurement from speakers. Booklets containing training materials were given to all of the respondents. At the end of the training, demonstrations of the COVID-19 health protocols (washing hands and wearing a mask) and measuring body temperature with an infrared thermometer were carried out. The respondents were required to fill in the pre-test and post-test questionnaire, before and after the training was conducted.

There are two questionnaires used in this study, the first was a demographic questionnaire consisting of respondents' name, gender, age, residence/ domicile, occupation, and last education. The second questionnaire consisted of 15 questions about respondents' knowledge regarding the COVID-19 pandemic disaster. These instruments were arranged based on the training material provided to determine the respondent's level of knowledge..$^{13}$ Each correct answer got a score of 1 , while the wrong answer was not counted. All correct answers were added up and presented in percentage. We divided the community's knowledge scores into three categories: good (76-100\%), average (56-75\%), and poor (< $56 \%) .{ }^{12}$ This scoring was used to determine the effect of the training given on the respondents' knowledge. The data were then analyzed using the Wilcoxon test. This study was reviewed and approved by the Medical and Health Research Ethics Committee of the Faculty of Medicine, Public Health and Nursing UGM, with the ethics code KE/0972/09/2020. Participants voluntarily agreed to participate in this 
Table 1. Characteristics of respondents $(n=29)$

\begin{tabular}{|c|c|c|}
\hline Characteristics & $f$ & $\%$ \\
\hline \multicolumn{3}{|l|}{ Gender } \\
\hline Male & 15 & 51.72 \\
\hline Female & 14 & 48.28 \\
\hline \multicolumn{3}{|l|}{ Age (years old) } \\
\hline $17-25$ & 1 & 3.45 \\
\hline $26-35$ & 1 & 3.45 \\
\hline $36-45$ & 13 & 44.83 \\
\hline $46-55$ & 7 & 24.14 \\
\hline $55-65$ & 7 & 24.14 \\
\hline \multicolumn{3}{|l|}{ Education } \\
\hline Didn't attend school & 1 & 3.45 \\
\hline Elementary School & 2 & 6.90 \\
\hline Junior High School & 3 & 10.34 \\
\hline Senior High School & 19 & 65.52 \\
\hline Diploma & 1 & 3.45 \\
\hline Undergraduate & 3 & 10.34 \\
\hline \multicolumn{3}{|l|}{ Occupation } \\
\hline Unemployed & 1 & 3.45 \\
\hline Housewife & 10 & 34.48 \\
\hline Farmer & 2 & 6.90 \\
\hline Civil Servant & 12 & 41.38 \\
\hline Entrepreneur & 2 & 6.90 \\
\hline Others & 2 & 6.90 \\
\hline \multicolumn{3}{|c|}{ Experience in attending similar training } \\
\hline Never been & 25 & 86.21 \\
\hline Ever been & 4 & 13.79 \\
\hline
\end{tabular}

study after being given an explanation and filling out informed consent forms.

\section{Result}

The distribution of the characteristics of the respondents in this study consisted of age, gender, education, occupation, and experience in attending similar training as shown in Table 1.

From 29 respondents, 15 (51.72\%) are men and $14(48.28 \%)$ are women. Respondents' ages range from 25 to 60 , and most of them (44.83\%) are aged between 36-45 years old. As many as 19 (65.52\%) respondents finished high school. Twelve (41.38\%) respondents work as civil servants, and 10 (34.48) respondents are housewives. Twenty-five (86.21\%) respondents had never attended similar training before.

Pre-test results showed that 17 (58\%) respondents have average knowledge. After the training, respondents were asked to fill in the same questionnaire and the results were 22 (75\%) respondents have good knowledge. The pre-test mean score is 9.93 , and the post-test mean score is 11.68 with a 1.75 score difference. From the cumulative score, we can see that there is significant knowledge improvement as seen from the $P$-value ( $P$ $<0.005$ ), in respondents' knowledge before and after the training. 
Table 2. Categories of knowledge based on pre-test and post-test score $(n=29)$

\begin{tabular}{lllll}
\hline \multirow{2}{*}{ Categories } & \multicolumn{2}{l}{$\begin{array}{l}\text { Pre-test } \\
\text { (mean= 9.93 } \pm \text { SD }=\mathbf{2 . 5 0 6 )}\end{array}$} & \multicolumn{2}{l}{$\begin{array}{l}\text { Post-test } \\
\text { (mean= 11.68 } \pm \text { SD= 2.237) }\end{array}$} \\
\cline { 2 - 5 } & $\mathbf{f}$ & $\%$ & $\mathbf{f}$ & \% \\
\hline Good knowledge & 7 & 24.14 & 22 & 75.86 \\
Average knowledge & 17 & 58.62 & 3 & 10.35 \\
Poor knowledge & 5 & 17.24 & 4 & 13.79 \\
\hline
\end{tabular}

\section{Discussion}

After identifying the vulnerable populations in the rural areas where people often neglect the important health protocols that are mandated by the government, this research was conducted to determine the effect of disaster training during the COVID-19 pandemic. Training was provided to demonstrate the importance of proper hand washing, avoiding crowds, and maintaining public safety by engaging in the current social restrictions that limit travel and large gatherings. The government encouraged the community to continue implementing the specific steps that can be taken to prevent and control COVID-19 transmission. The public must have sufficient knowledge and skills as a capacity to deal with the COVID-19 pandemic. After we conducted the disaster preparedness training related to COVID-19, we found that overall there was significant knowledge improvement after the training.

Based on the test score in Table 2, it is known that before the training, most respondents (58.62\%) have average knowledge and after the training, most respondents (75.68\%) have more knowledge. This indicates there was knowledge improvement. This is in line with the results of research where there was an increase in the knowledge of respondents who attended disaster preparedness training. ${ }^{8}$ Respondents learned about COVID-19 prevention and control measures through the training. Learning is a process that learners go through to change behavior, which allows a person to acquire, update, enhance, or complement knowledge, skills, and attitudes in order to function effectively in ongoing changes. ${ }^{9}$ Learning methods used in the training such as lectures and demonstration with practice can increase a person's knowledge. ${ }^{10}$

The disaster preparedness training had an impact on a significant increase in knowledge $(P$ $<0.005$ ). Knowledge and skills are elements of capacity at the individual level that can be gained through training. Improvement of knowledge after the training is part of the stimulation process in capacity development. ${ }^{4}$ Knowledge is essential in this unprecedented pandemic situation. Thailand and Singapore are examples where one of the COVID-19 containment measures is community education, in which the government provides the latest and accurate information about COVID-19, and continues to encourage people to implement health protocols. Along with other containment measures such as surveillance, mass testing, lockdown, and border control measures, these efforts can successfully flatten the curve and prevent the health system from collapsing. ${ }^{11,12}$

This increase is expected to change the community's behavior and increase their selfawareness about the importance of preventing the spread of COVID-19. In addition, people who take part in the training are expected to be able to educate those around them. That way, the community can support the government in dealing with the COVID-19 pandemic crisis because basically the main control comes from individual behavior. ${ }^{13}$

\section{Conclusions}

There is a significant effect of disaster preparedness training on public knowledge about COVID-19. The capacity of the community in dealing with the COVID-19 pandemic is very important. With the role of the community, prevention and control measures can be implemented down to the smallest unit of 
society. Various methods adapted to the conditions of COVID-19 can be conducted in an ongoing manner, so that community can have up-to-date knowledge and information.

The limitation is that the study only assessed the knowledge through pretest and posttest. Further research that assesses the practical skills of the disaster preparedness training (washing hands, wearing a mask and measuring body temperature with an infrared thermometer) is needed to understand the COVID-19 health protocols performed by the respondents. Moreover, further studies with larger sample sizes are needed to draw a firm conclusion.

\section{Acknowledgment}

The authors want to express their gratitude to the School of Nursing, Faculty of Medicine, Public Health and Nursing, Universitas Gadjah Mada, that gave the authors a chance to conduct the study, and to the head of Banjararum Village, Kulon Progo Regency who gave permission and access to data collection among the rural society.

\section{References}

1. WHO. Coronavirus disease (COVID-19) [Internet]. 2020 [cited 2021 Jan 6]. Available from: https:// www.who.int/emergencies/diseases/novelcoronavirus-2019/question-and-answers-hub/ q-a-detail/coronavirus-disease-covid-19

2. WHO. Virtual Press Conference on Covid-19 - 11 March 2020 [Internet]. 2020 [cited 2021 Jan 6]. Available from: https://www.who.int/ docs/default-source/coronaviruse/transcripts/ who-audio-emergencies-coronavirus-pressconference-full-and-final-11mar 2020. pdf?sfvrsn=cb432bb3_2

3. Gilmore B, Ndejjo R, Tchetchia A, De Claro $V$, Mago $E$, Diallo $A A$, et al. Community engagement for COVID-19 prevention and control: a rapid evidence synthesis. BMJ Glob Heal. 2020;5(10):3188.

4. UN.Sendai Framework for Disaster Risk Reduction 2015 - 2030 [Internet]. 2015. Available from: https://www.undrr.org/publication/sendaiframework-disaster-risk-reduction-2015-2030

5. CADRI. Basics of Capacity Development for
Disaster Risk Reduction. 2011;1-30. Available from: https://www.undrr.org/publication/ basics-capacity-development-disaster-riskreduction

6. UNISDR. Words Into Action: A Guide for Implementing the Hyogo Framework Hyogo Framework for Action 2005-2015: Building the resilience of nations and communities to disasters International Strategy for Disaster Reduction [Internet]. 2007 [cited 2021 Jul 22]. p. 4. Available from: https://www.preventionweb. net/files/594_10382.pdf

7. Weichselgartner J, Pigeon P. The role of knowledge in disaster risk reduction. Int J Disaster Risk Sci. 2015;6(2):107-16.

8. Lee M, Kang BA, You M. Knowledge, attitudes, and practices (KAP) toward COVID-19: a crosssectional study in South Korea. BMC Public Health. 2021;21(1):1-10.

9. Yanti B, Wahyudi E, Wahiduddin W, Novika RGH, Arina YMD, Martani NS, et al. Community knowledge, attitudes, and behavior towards social distancing policy as prevention transmission of covid-19 in Indonesia. J Adm Kesehat Indones. 2020;8(2):4.

10. Dahlan MS. Besar Sampel Dalam Penelitian Kedokteran dan Kesehatan. 4th ed. Epidemiologi Indonesia; 2016. 139 p.

11. Chen $\mathrm{X}$, Chen HH. Differences in preventive behaviors of covid-19 between urban and rural residents: Lessons learned from a cross-sectional study in china. Int J Environ Res Public Health. 2020;17(12):1-14.

12. Mirzaei S, Eftekhari A, Sadeghian MR, Kazemi $S$, Nadjarzadeh A. The effect of disaster management training program on knowledge, attitude, and practice of hospital staffs in natural disasters. J Disaster Emerg Res. 2019;2(1):9-16.

13. Bohariand JA, Widana IK. Short training to improve knowledge of disaster management on basic level: A before and after study. IOP Conf Ser Earth Environ Sci. 2021;708(1): 012096.

14. Masturoh I, Anggita T N. Metodologi Penelitian Kesehatan[Internet].1sted.JakartaSelatan:Pusat Pendidikan Sumber Daya Manusia Kesehatan Badan Pengembangan dan Pemberdayaan SDM Kesehatan; 2018 [cited 2021 Aug 3]. 61 p. 
Available from: http://bppsdmk.kemkes.go.id/ pusdiksdmk/wp-content/uploads/2018/09/ Metodologi-Penelitian-Kesehatan_SC.pdf

15. Kuntjoro I, Claramita M, Istiono W. Evaluation of community based disaster preparedness training for UGM health study program students in 2016. Rev Prim Care Pract Educ. 2019;2(1):15.

16. Prakash R, Sharma N, Advani U. Learning process and how adults learn. Int J Acad Med. 2019;5(1):75.

17. Patrick J. Creative facilitation techniques for training [Internet]. McDonald A, editor. Vol. 28. ASTD Press; 2011 [cited 2021 Jan 8]. 5 p.
Available from: https://books.google.co.id/

18. Lin RJ, Lee $T H$, Lye $D C B$. From SARS to COVID-19: The Singapore journey. Med J Aust. 2020;212(11):497-502.e1.

19. Namwat C, Suphanchaimat R, Nittayasoot N. Thailand's response against Coronavirus Disease 2019: challenges and lessons learned. Outbreak, Surveillance, Investig Response. 2020;13(1):337.

20. Golechha M. COVID-19, India, lockdown and psychosocial challenges: What next? Int J Soc Psychiatry. 2020;66(8):830-2. 